\title{
Keberhasilan Implementasi Penggunaan Sistem Informasi Manajemen dan Akuntansi Barang Milik Negara dan Kinerja Individu
}

\author{
Ni Wayan Ardyanti ${ }^{1}$ \\ Fakultas Ekonomi dan Bisnis \\ Universitas Udayana, Indonesia
}

\author{
Dodik Ariyanto ${ }^{2}$ \\ Fakultas Ekonomi dan Bisnis \\ Universitas Udayana, Indonesia
}

\begin{abstract}
Surel : ardyanti1998@gmail.com
ABSTRAK

Penelitian bertujuan untuk mengetahui pengaruh penggunaan sistem informasi dan kepuasan pengguna pada kinerja karyawan. Penelitian dilakukan di Kantor Pelayanan Kekayaan Negara dan Lelang (KPKNL) wilayah Denpasar. Metode penentuan sampel yang digunakan adalah nonprobability sampling berdasarkan teknik sampling jenuh. Teknik analisis yang digunakan adalah analisis regresi linear berganda. Hasil analisis penelitian menunjukan kualitas sistem, kualitas informasi, kualitas kolaborasi dan kualitas layanan berpengaruh positif dan signifikan pada penggunaan sistem dan kepuasan pengguna, serta penggunaan sistem dan kepuasan pengguna berpengaruh positif dan signifikan pada kinerja karyawan satuan kerja KPKNL wilayah Denpasar.

Kata Kunci: $\quad$ Penggunaan Sistem; Kepuasan Pengguna; Kinerja Karyawan; Simak BMN.

\section{The Successful Implementation of the Use of Management and Accounting Information Systems for State Property and Individual Performance}

\section{ABSTRACT}

This study aims to determine the effect of the use of information systems and user satisfaction on employee performance. This research was conducted at the KPKNL Work Unit in Denpasar. The sampling method used in this study is nonprobability sampling based on saturated sampling technique. The analysis technique used is multiple linear regression analysis. The results of the analysis of this study stated that the quality of the system, the quality of information, the quality of collaboration and the quality of service had a positive and significant effect on system use and user satisfaction, and the use of the system and user satisfaction had a positive and significant effect on the performance of KPKNL work unit employees in denpasar area.

Keywords: System Usage; User Satisfaction; Employee Performance; Simak BMN.

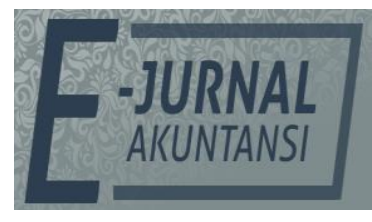

e-ISSN 2302-8556

Vol. 30 No. 9

Denpasar, September 2020

Hal. 2351-2365

DOI:

10.24843/EJA.2020.v30.i09.p14

PENGUTIPAN:

Ardyanti, N. W. \& Ariyanto, D. (2020). Keberhasilan Implementasi Penggunaan Sistem Informasi Manajemen dan Akuntansi Barang Milik Negara dan Kinerja Individu. E-Jurnal Akuntansi, 30(9), 2351-2365

RIWAYAT ARTIKEL:

Artikel Masuk: 17 Februari 2020 Artikel Diterima: 14 Juli 2020

Artikel dapat diakses : https://ojs.unud.ac.id/index.php/Akuntansi/index 


\section{PENDAHULUAN}

Kinerja individu atau kinerja karyawan merupakan tingkat keberhasilan dari seseorang selama periode tertentu dalam melaksanakan tugas dibandingkan dengan kemungkinan yang telah ditentukan dan disepakati secara bersama DeLone \& McLean (1992) dan Marlinawati (2013). Perkembangan teknologi informasi di era modern ini telah menunjukkan perkembangan yang sangat pesat terutama terhadap sistem informasi akuntansi (Wirawan, 2016) dengan melakukan digitalisasi (Yuhelson et al., 2020). Semakin banyak instansi pemerintahan sudah beralih menggunakan teknologi komputer dalam mengelola data atau transaksi Yuhelson et al., (2020) yang dilakukan oleh organisasi menjadi suatu yang tepat, akurat dan relevan sehingga memudahkan dalam mengambil keputusan (Rahardiyanti, 2012).

Salah satu sistem informasi akuntansi yang diterapkan di instansi pemerintah yaitu sistem informasi manajemen dan akuntansi barang milik negara (SIMAK BMN). SIMAK BMN diterapkan oleh satuan kerja yang terdaftar pada Kantor Pelayanan Kekayaan Negara dan Lelang (KPKNL) Denpasar. SIMAK BMN merupakan sub sistem berupa rangkaian prosedur yang saling berhubungan dan digunakan dalam mengolah dokumen sumber, dengan tujuan menghasilkan informasi laporan barang milik negara (BMN) serta laporan manajerial lainnya yang sesuai dengan ketentuan yang berlaku untuk menunjang fungsi pengelolaan BMN (Sabario \& Jaya, 2017).

Rahardiyanti (2012) sebelumnya sempat meneliti tentang SIMAK BMN yang diimplementasikan di lingkungan Departemen Kebudayan dan Pariwisata Republik Indonesia terdapat faktor-faktor yang berpengaruh terhadap meningkatnya efektivitas dari SIMAK BMN yaitu, kualitas sistem, kualitas informasi, kegunaan, kemudahan pengguna, tingkat pendidikan dan lama penggunaan SIMAK BMN. Namun, dalam penelitian Rahardiyanti (2012) kualitas informasi tidak berpengaruh secara signifikan terhadap kepuasan pengguna SIMAK BMN.

SIMAK BMN diterapkan oleh 115 satuan kerja KPKNL wilayah Denpasar yang memiliki pandangan yang berbeda-beda terhadap penggunaan sistem informasi. Setiap satuan kerja setidaknya memiliki satu karyawan yang bertugas sebagai operator yang bertugas dalam melakukan pencatatan maupun transaksi barang milik negara yang terdapat pada masing-masing satuan kerja menggunakan aplikasi SIMAK-BMN. Sehingga hal ini memungkinkan adanya pengaruh terhadap kepuasan pengguna maupun kinerja individu atau karyawan DeLone \& McLean (1992) pada satuan kerja KPKNL wilayah Denpasar.

Teori yang digunakan adalah teori Technology Acceptance Model (TAM) yang merupakan teori mengenai penggunaan teknologi informasi yang dianggap berpengaruh serta umumnya digunakan untuk menjelaskan penerimaan individual terhadap penggunaan sistem teknologi informasi (Jogiyanto, 2007). Teori Kolaborasi (Collaboration Theory) merupakan upaya yang dilakukan oleh berbagai pihak untuk mencapai tujuan yang sama dan membutuhkan banyak waktu untuk melakukan konikasi dalam menyelesaikan tugasnya (Bhatti, et al. 2018). Model Kesuksesan DeLone \& McLean (1992a; 2003b) digunakan untuk mengukur kesuksesan sistem informasi yang terdiri dari tujuh pengukuran 
yaitu, kualitas sistem, kualitas informasi, kualitas layanan, penggunaan, kepuasan pengguna dan kinerja karyawan.

Kualitas sistem merupakan pengukuran proses sistem informasi yang berfokus pada hasil interaksi antar pengguna dan system (DeLone \& McLean, 1992). Berdasarkan teori TAM penggunaan teknologi informasi berpengaruh dan umumnya digunakan untuk menjelaskan penerimaan individual terhadap penggunaan sistem teknologi informasi (Jogiyanto, 2007). Kualitas sistem merupakan karakteristik dari informasi yang melekat mengenai sistem itu sendiri dimana kualitas sistem merupakan kombinasi antara kualitas hardware dan software itu sendiri (DeLone \& McLean, 1992). Menurut Ikhsani \& Yusuf (2018) kualitas sistem berpengaruh positif pada penggunaan sistem, hal tersebut karena kualitas sistem yang ada sudah mampu dalam menyelesaikan pekerjaan pengguna. Hasil penelitian ini sejalan dengan penelitian (Krisdiantoro et al.,. 2018). Berdasarkan pernyataan tersebut maka dirumuskan hipotesis yaitu sebagai berikut.

$\mathrm{H}_{1}$ : Kualitas sistem berpengaruh positif pada penggunaan sistem.

Kualitas informasi merupakan output yang dihasilkan oleh sistem informasi yang digunakan oleh pengguna (DeLone \& McLean, 1992). Berdasarkan teori TAM penggunaan teknologi informasi digunakan untuk menjelaskan penerimaan individual pada penggunaan sistem teknologi informasi (Jogiyanto, 2007). Menurut Purwanto \& Pawirosumarto (2017) kualitas sistem berpengaruh signifikan terhadap penggunaan sistem. Hasil penelitian ini sejalan dengan penelitian Subchan et al., (2012) \& Wiratama, (2013). Berdasarkan uraian tersebut maka rumusan hipotesisnya yaitu sebagai berikut.

$\mathrm{H}_{2}$ : Kualitas informasi berpengaruh positif pada penggunaan sistem.

Kualitas kolaborasi dari suatu sistem memiliki dampak langsung dan tidak langsung terhadap pengguna sistem (Bhatti et al., 2018). Berdasarkan teori kolaborasi, kolaborasi merupakan merupakan individu yang bekerjasama dalam mencapai suatu tujuan secara bersama-sama. Menurut He \& Yang (2016) kualitas kolaborasi berpengaruh terhadap penggunaan sistem. Hasil penelitian ini sejalan dengan penelitian Bhatti et al. (2018) \& Subchan et al.,, (2012). Berdasarkan uraian tersebut maka dapat dirumuskan hipotesis yaitu sebagai berikut.

$\mathrm{H}_{3}$ : Kualitas kolaborasi berpengaruh positif pada penggunaan sistem.

Kualitas layanan merupakan perbandingan antara seberapa jauh antara harapan dan kenyataan yang diterima pengguna terhadap layanan sistem (DeLone \& McLean, 2003). Berdasarkan teori TAM penggunaan teknologi informasi menjelaskan penerimaan individual pada penggunaan sistem teknologi informasi (Jogiyanto, 2007). Menurut Purwanto \& Pawirosumarto (2017) kualitas layanan berpengaruh positif pada penggunaan sistem. Hasil penelitian ini sejalan dengan penelitian Groho et al.,(2014) \& Ikhsani \& Yusuf (2018). Berdasarkan uraian tersebut maka rumusan hipotesis yaitu sebagai berikut.

$\mathrm{H}_{4}$ : Kualitas layanan berpengaruh positif pada penggunaan sistem.

Kualitas sistem merupakan karakteristik dari sistem informasi yang melekat pada sistem itu sendiri dimana kualitas sistem merupakan kualitas dari gabungan antara hardware dan software itu sendiri DeLone \& McLean, (1992). Berdasarkan teori TAM penggunaan komputer ditentukan oleh tujuan perilaku, 
yang dimana tujuan perilaku dikaji secara bersama-sama dan ditentukan oleh sikap individu pada penggunaan sistem dan persepsi pengguna (Iranto, 2012). Menurut Rukmiyati \& Budiartha (2015) kualitas sistem berpengaruh pada kepuasan pengguna. Hasil penelitian ini sejalan dengan penelitian Rahardiyanti (2012) \& Swandewi et al., (2017). Berdasarkan penjelasan diatas maka dapat dirumuskan hipotesis yaitu sebagai berikut.

$\mathrm{H}_{5}$ : Kualitas sistem berpengaruh positif pada kepuasan pengguna.

Kualitas informasi merupakan output yang dihasilkan oleh sistem informasi yang digunakan oleh pengguna (DeLone \& McLean, 1992). Berdasarkan teori TAM penggunaan komputer ditentukan oleh tujuan perilaku, yang dimana tujuan perilaku ditinjau secara bersama-sama yang ditentukan oleh sikap individu pada penggunaan sistem dan persepsi pengguna (Iranto, 2012). Menurut Shinta (2018) kualitas informasi berpengaruh terhadap kepuasan pengguna. Hasil penelitian ini sejalan dengan penelitian Prasojo \& Pratomo (2015), Purwanto \& Pawirosumarto (2017) \& Swandewi et al., (2017). Berdasarkan pernyatan tersebut maka rumusan hipotesisnya yaitu sebagai berikut.

$\mathrm{H}_{6}$ : Kualitas informasi berpengaruh positif pada kepuasan pengguna.

Kualitas kolaborasi dari suatu sistem memiliki dampak langsung dan tidak langsung terhadap pengguna sistem (Bhatti et al., 2018). Berdasarkan teori kolaborasi, kolaborasi merupakan merupakan individu yang bekerjasama dalam mencapai suatu tujuan secara bersama-sama. Menurut Subchan et al, (2012) kualitas kolaborasi berpengaruh signifikan pada kepuasan pengguna sistem informasi. Hasil penelitian ini sejalan dengan penelitian He \& Yang (2016) \& Bhatti et al. (2018). Berdasarkan uraian tersebut maka dapat dirumuskan hipotesis yaitu sebagai berikut.

$\mathrm{H}_{7}$ : Kualitas kolaborasi berpengaruh positif pada kepuasan pengguna.

Kualitas layanan merupakan perbandingan antara seberapa jauh antara harapan dan kenyataan yang diterima pengguna cara membandingkan persepsi para pengguna atas layanan yang diterima oleh pengguna (DeLone \& McLean, 2003). Berdasarkan teori TAM penggunaan komputer ditentukan oleh tujuan perilaku, yang dimana tujuan perilaku ditinjau bersama-sama yang ditentukan oleh sikap individu pada penggunaan sistem dan persepsi pengguna (Iranto, 2012). Menurut Septianita et al., (2014) kualitas layanan berpengaruh positif terhadap kepuasan pengguna. Hasil penelitian ini sejalan dengan penelitian Prasojo \& Pratomo (2015) \& Shinta (2018). Berdasarkan uraian tersebut maka dapat rumusan hipotesisnya yaitu sebagai berikut.

$\mathrm{H}_{8}$ : Kualitas layanan berpengaruh positif pada kepuasan pengguna.

Penggunaan merupakan tingkatam dan cara dimana pengguna dapat memanfaatkan kemampuan dari suatu sistem informasi. Penggunaan teknologi informasi terdiri dari kemudahan penggunaan teknologi informasi dan pemanfaatan teknologi informasi (Muzakki et al., 2016). Berdasarkan teori TAM penggunaan teknologi informasi mempengaruhi serta umumnya digunakan untuk memperjelas penerimaan individual terhadap penggunaan sistem teknologi informasi (Jogiyanto, 2007). Menurut penelitian Marlinawati \& Suryana (2013) penggunaan sistem berpengaruh positif pada kinerja karyawan. Hasil penelitian ini sejalan dengan penelitian Antasari (2015). Berdasarkan penjelasan tersebut maka dapat dirumuskan hipotesis yaitu sebagai berikut. 
$\mathrm{H}_{9}$ : Penggunaan sistem berpengaruh positif pada kinerja karyawan.

Kepuasan pengguna merupakan hal-hal yang meliputi penilaian mencakup pengalaman pemakai sistem ketika menggunakan sistem informasi yang nantinya berdampak potensial dari sistem informasi itu sendiri (Seddon \& Kiew, 1996). Berdasarkan teori TAM penggunaan komputer ditentukan oleh tujuan perilaku, yang dimana tujuan perilaku ditinjau secara bersama-sama yang ditentukan oleh sikap individu pada penggunaan sistem dan persepsi pengguna (Iranto, 2012). Menurut Wijaya \& Hamidah (2018) kepuasan pengguna berpengaruh signifikan terhadap kinerja karyawan. Hasil penelitian ini sejalan dengan penelitian Krisna Dewi \& Mertha (2016) \& Iranto, (2012). Berdasarkan uraian tersebut maka dapat dirumuskan hipotesis yaitu sebagai berikut.

$\mathrm{H}_{10}$ : Kepuasan pengguna berpengaruh positif pada kinerja karyawan.

Berdasarkan teori dan hipotesis yang telah dijelaskan sebelumnya maka, dapat digambarkan kerangka konseptual yaitu sebagai berikut.

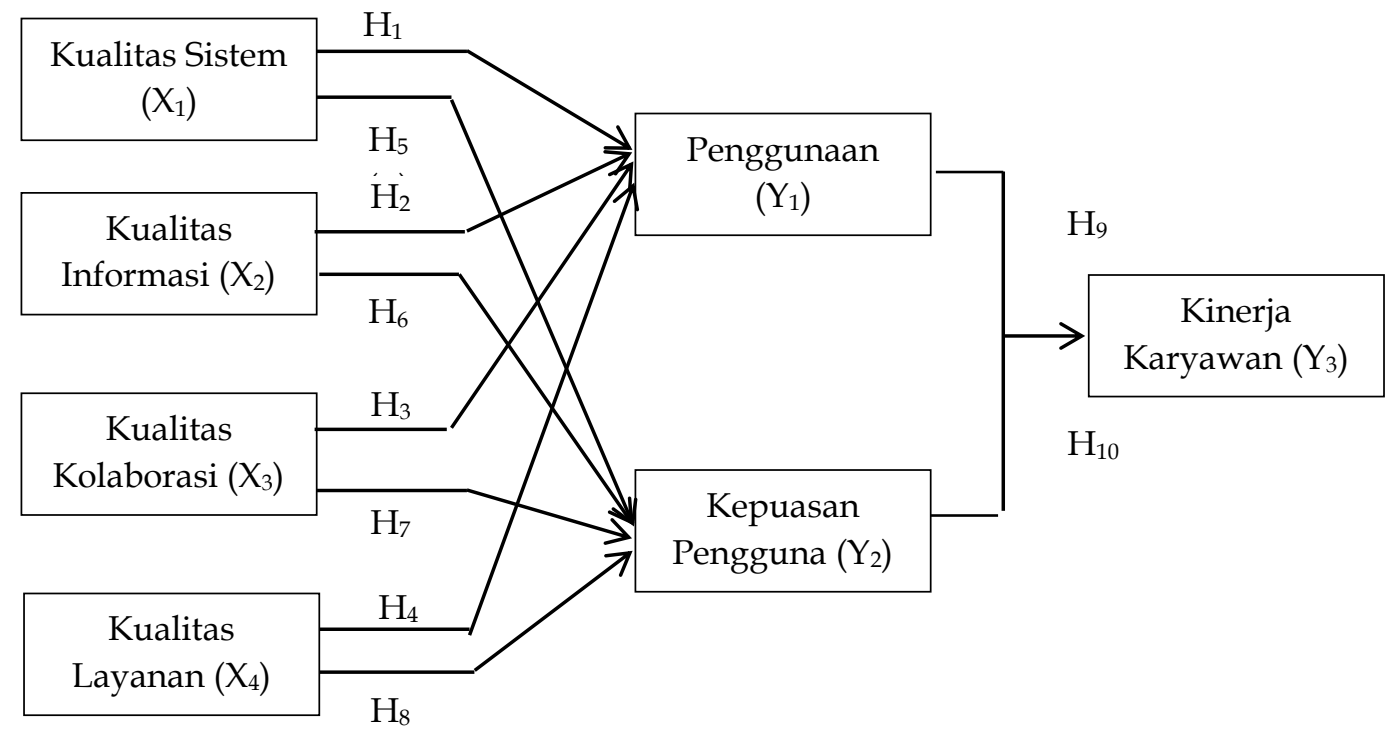

Sumber: Data Penelitian, 2020

\section{METODE PENELITIAN}

Penelitian ini dilakukan pada karyawan selaku operator SIMAK BMN satuan kerja KPKNL wilayah Denpasar. KPKNL Denpasar berlokasi di Gedung Keuangan Negara (GKN) I Jl. DR, Kusumaatmaja Renon, Denpasar. Lokasi penelitian ini dipilih dengan alasan bahwa satuan kerja yang terdaftar di KPKNL Denpasar menggunakan aplikasi SIMAK BMN yang merupakan objek penelitian yang dilakukan oleh peneliti. Objek dari penelitian ini adalah kualitas sistem, kualitas informasi, kualitas kolaborasi dan kualitas layanan dari SIMAK BMN, serta penggunaan sistem dan kepuasan pengguna SIMAK BMN yang memengaruhi kinerja karyawan pada satuan kerja KPKNL wilayah Denpasar.

Populasi yang digunakan dalam penelitian ini adalah jumlah satuan kerja KPKNL wilayah Denpasar yang berjumlah sebanyak 115 satuan kerja. Sampel yang digunakan dalam penelitian ini yakni berjumlah 115 satuan kerja KPKNL wilayah Denpasar. Sampel dalam penelitian ini yaitu dipilihnya satu karyawan 
yang bertugas sebagai operator SIMAK BMN di masing-masing satuan kerja KPKNL wilayah Denpasar. Metode penentuan sampel yang digunakan adalah nonprobability sampling dengan menggunakan teknik sampling jenuh yang dimana semua anggota populasi digunakan sebagai sampel. Peneliti melakukan penyebaran kuisioner sebanyak 115 eksemplar yaitu sebanyak jumlah sampel yang diteliti.

Analisis data yang digunakan dalam penelitian ini yaitu analisis regresi linear berganda dengan tingkat signifikansi 5\%. Pengujian ini dilakukan dengan menggunakan bantuan program SPSS. Model regresi linear berganda dirumuskan sebagai berikut:

$Y_{1}=\alpha+\beta_{1} X_{1}+\beta_{2} X_{2}+\beta_{3} X_{3}+\beta_{4} X_{4}+\varepsilon$

$Y_{2}=\alpha+\beta_{1} X_{1}+\beta_{2} X_{2}+\beta_{3} X_{3}+\beta_{4} X_{4}+\varepsilon$

$Y_{3}=\alpha+\beta_{5} Y_{1}+\beta_{6} Y_{2}+\varepsilon$

Keterangan:

$$
\begin{array}{ll}
\mathrm{Y}_{1} & =\text { Penggunaan } \\
\mathrm{Y}_{2} & =\text { Kepuasan Pengguna } \\
\mathrm{Y}_{3} & =\text { Kinerja Karyawan } \\
\alpha & =\text { Konstanta } \\
\beta_{\mathrm{I}} & =\text { Koefisien Regresi, } \mathrm{i}=1,2,3,4,5,6 \\
\mathrm{X}_{1} & =\text { Kualitas Sistem } \\
\mathrm{X}_{2} & =\text { Kualitas Informasi } \\
\mathrm{X}_{3} & =\text { Kualitas Kolaborasi } \\
\mathrm{X}_{4} & =\text { Kualitas Layanan } \\
\varepsilon & =\text { Standard Error }
\end{array}
$$

\section{HASIL DAN PEMBAHASAN}

Sampel yang digunakan dalam penelitian ini yaitu sebanyak 115 satuan kerja. Pengumpulan data dilakukan melalui penyebaran kuisioner ke setiap satuan kerja, namun dari 115 kuisioner yang disebar terdapat 10 buah kuesioner yang tidak dikembalikan. Berdasarkan proses dan hasil seleksi sampel, sebanyak 105 responden yang dijadikan sampel. Pengujian data dalam penelitian ini menggunakan software SPSS for Windows, dan diperoleh hasil Tabel 1.

Berdasarkan pada Tabel 1, menunjukkan bahwa variabel penggunaan memiliki nilai rata-rata sebesar 11,31 dengan nilai minimum 4,00 dan nilai maksimum 15,00 serta memiliki nilai standar deviasi sebesar 2,33. Variabel kepuasan pengguna memiliki nilai rata-rata sebesar 11,63 dengan nilai minimum 4,00 dan nilai maksimum 15,00 serta memiliki nilai standar deviasi sebesar 2,17. Variabel kinerja karyawan memiliki nilai rata-rata sebesar 23,63 dengan nilai minimum 14,00 dan nilai maksimum 30,00 serta memiliki nilai standar deviasi sebesar 3,61. Hal ini mengindikasikan bahwa penyebaran data menunjukkan hasil yang normal dan tidak bias.

Variabel kualitas sistem memiliki nilai rata-rata sebesar 19,17 dengan nilai minimum 8,00 dan nilai maksimum 25,00 serta memiliki nilai standar deviasi sebesar 4,09. Variabel kualitas informasi memiliki nilai rata-rata sebesar 19,03 dengan nilai minimum 8,00 dan nilai maksimum 25,00 serta memiliki nilai standar deviasi sebesar 3,59. Variabel kualitas kolaborasi memiliki nilai rata- 
rata sebesar 20,72 dengan nilai minimum 15,00 dan nilai maksimum 25,00 serta memiliki nilai standar deviasi sebesar 2,67. Variabel kualitas layanan memiliki nilai rata-rata sebesar 19,21 dengan nilai minimum 8,00 dan nilai maksimum 25,00 serta memiliki nilai standar deviasi sebesar 3,26. Hal ini mengindikasikan bahwa penyebaran data menunjukkan hasil yang normal dan tidak bias.

Tabel 1. Hasil Statistik Deskriptif

\begin{tabular}{lrrrrr}
\hline \multicolumn{1}{c}{ Variabel } & $\mathrm{N}$ & \multicolumn{1}{c}{ Min. } & Maks. & Mean & $\begin{array}{c}\text { Std. } \\
\text { Deviation }\end{array}$ \\
\hline Penggunaan $\left(\mathrm{Y}_{1}\right)$ & 105 & 4,00 & 15,00 & 11,31 & 2,33 \\
Kepuasan Pengguna $\left(\mathrm{Y}_{2}\right)$ & 105 & 4,00 & 15,00 & 11,63 & 2,17 \\
Kinerja Karyawan $\left(\mathrm{Y}_{3}\right)$ & 105 & 14,00 & 30,00 & 23,63 & 3,61 \\
Kualitas Sistem $\left(\mathrm{X}_{1}\right)$ & 105 & 8,00 & 25,00 & 19,17 & 4,09 \\
Kualitas Informasi $\left(\mathrm{X}_{2}\right)$ & 105 & 8,00 & 25,00 & 19,03 & 3,59 \\
Kualitas Kolaborasi $\left(\mathrm{X}_{3}\right)$ & 105 & 15,00 & 25,00 & 20,72 & 2,67 \\
Kualitas Layanan $\left(\mathrm{X}_{4}\right)$ & 105 & 8,00 & 25,00 & 19,21 & 3,26 \\
\hline
\end{tabular}

Sumber: Data Penelitian, 2020

Hasil uji normalitas pada Tabel 2, menunjukkan bahwa koefisien Asymp. Sig (2-tailed) pada model persamaan regresi struktur 1 sebesar 0,610, struktur 2 sebesar 0,963, dan struktur 3 sebesar 0,592. Hasil tersebut menunjukkan bahwa model persamaan regresi pada struktur 1,2 dan 3 berdistribusi norma karena nilai Asymp. Sig (2-tailed) lebih besar dari nilai alpha 0,05.

Tabel 2. Hasil Uji Normalitas

\begin{tabular}{lrrr}
\hline & $\begin{array}{c}\text { Unstandardized } \\
\text { Residual } \\
\text { Srtuktur 1 }\end{array}$ & $\begin{array}{c}\text { Unstandardized } \\
\text { Residual } \\
\text { Struktur 2 }\end{array}$ & $\begin{array}{c}\text { Unstandardized } \\
\text { Residual } \\
\text { Struktur 3 }\end{array}$ \\
\hline Nl & 105 & 105 & 105 \\
Kolmogorov-Smirnov Z & 0,760 & 0,501 & 0,771 \\
Asymp.Sig.(2-tailed) & 0,610 & 0,963 & 0,592 \\
\hline
\end{tabular}

Sumber: Data Penelitian, 2020

Berdasarkan Tabel 3, menunjukkan bahwa nilai tolerance dari setiap variabel lebih besar dari 10\% dan nilai dari VIF lebih kecil dari 10, hal ini berarti model persamaan regresi bebas dari multikolinearitas.

Tabel 3. Hasil Uji Multikoleniaritas

\begin{tabular}{|c|c|c|c|}
\hline Persamaan Struktur & Variabel & Tolerance & VIF \\
\hline \multirow[t]{4}{*}{$Y_{1}=a+\beta_{1} X_{1}+\beta_{2} X_{2}+\beta_{3} X_{3}+\beta_{4} X_{4}+\varepsilon$} & Kualitas sistem $\left(\mathrm{X}_{1}\right)$ & 0,216 & 4,622 \\
\hline & Kualitas informasi $\left(\mathrm{X}_{2}\right)$ & 0,305 & 3,278 \\
\hline & Kualitas kolaborasi $\left(\mathrm{X}_{3}\right)$ & 0,492 & 2,034 \\
\hline & Kualitas layanan $\left(\mathrm{X}_{4}\right)$ & 0,247 & 4,041 \\
\hline \multirow{4}{*}{$Y_{2}=a+\beta_{1} X_{1}+\beta_{2} X_{2}+\beta_{3} X_{3}+\beta_{4} X_{4}+\varepsilon$} & Kualitas sistem $\left(X_{1}\right)$ & 0,216 & 4,622 \\
\hline & Kualitas informasi $\left(X_{2}\right)$ & 0,305 & 3,278 \\
\hline & Kualitas kolaborasi $\left(\mathrm{X}_{3}\right)$ & 0,492 & 2,034 \\
\hline & Kualitas layanan $\left(\mathrm{X}_{4}\right)$ & 0,247 & 4,041 \\
\hline \multirow[t]{2}{*}{$Y_{3}=a+\beta_{5} Y_{1}+\beta_{6} Y_{2}+\varepsilon$} & Penggunaan $\left(\mathrm{Y}_{1}\right)$ & 0,322 & 3,104 \\
\hline & $\begin{array}{l}\text { Kepuasan pengguna } \\
\left(\mathrm{Y}_{2}\right)\end{array}$ & 0,322 & 3,104 \\
\hline
\end{tabular}

Sumber: Data Penelitian, 2020

Berdasarkan Tabel 4, dapat dilihat bahwa signifikansi dari setiap variabel lebih besar dari 0,05 yang berarti model regresi analisis linear berganda struktur 1 bebas uji heteroskedastisitas. 
Tabel 4. Hasil Uji Heterokedastisitas Struktur 1

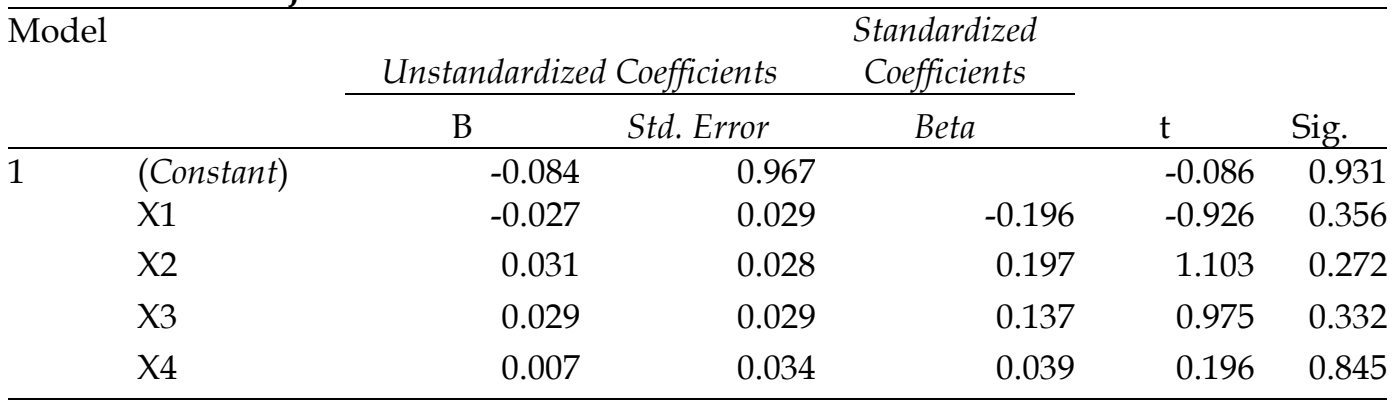

Sumber: Data Penelitian, 2020

Berdasarkan Tabel 5, dapat dilihat bahwa signifikansi dari setiap variabel lebih besar dari 0,05 yang berarti model regresi analisis linear berganda struktur 2 bebas uji heteroskedastisitas.

Tabel 5. Hasil Uji Heterokedastisitas Struktur 2

\begin{tabular}{|c|c|c|c|c|c|c|}
\hline \multirow{2}{*}{\multicolumn{2}{|c|}{ Model }} & \multicolumn{2}{|c|}{ Unstandardized Coefficients } & \multicolumn{3}{|l|}{$\begin{array}{c}\text { Standardized } \\
\text { Coefficients }\end{array}$} \\
\hline & & B & Std. Error & Beta & $\mathrm{t}$ & Sig. \\
\hline \multirow[t]{5}{*}{1} & (Constant) & 1.520 & 0.854 & & 1.780 & 0.078 \\
\hline & $\mathrm{X} 1$ & -0.002 & 0.026 & -0.019 & -0.087 & 0.931 \\
\hline & $\mathrm{X} 2$ & 0.000 & 0.025 & 0.003 & 0.015 & 0.988 \\
\hline & X3 & -0.024 & 0.026 & -0.132 & -0.928 & 0.356 \\
\hline & X4 & -0.016 & 0.030 & -0.106 & -0.533 & 0.596 \\
\hline
\end{tabular}

Sumber: Data Penelitian, 2020

Berdasarkan Tabel 6, dapat dilihat bahwa signifikansi dari setiap variabel lebih besar dari 0,05 yang berarti model regresi analisis linear berganda struktur 3 bebas uji heteroskedastisitas.

Tabel 6. Hasil Uji Heterokedastisitas Struktur 3

\begin{tabular}{|c|c|c|c|c|c|c|}
\hline \multicolumn{2}{|c|}{ Model } & \multicolumn{5}{|c|}{ Standardized } \\
\hline & & \multicolumn{2}{|c|}{ Unstandardized Coefficients } & \multirow{2}{*}{$\frac{\text { Coefficients }}{\text { Beta }}$} & \multirow[b]{2}{*}{$\mathrm{t}$} & \multirow[b]{2}{*}{ Sig. } \\
\hline & & B & Std. Error & & & \\
\hline \multirow[t]{3}{*}{1} & (Constant) & 2.451 & 0.789 & & 3.107 & 0.002 \\
\hline & Y1 & 0.085 & 0.108 & 0.136 & 0.783 & 0.436 \\
\hline & Y2 & -0.131 & 0.116 & -0.195 & -1.127 & 0.262 \\
\hline
\end{tabular}

Sumber: Data Penelitian, 2020

Pengujian data pada penelitian ini menggunakan teknik analisis regresi linear berganda. Perhitungan uji regresi linier berganda dilakukan dengan menggunakan software SPSS for Windows. Perhitungan uji regresi linear berganda dilakukan sebanyak 3 kali yang terdiri dari uji regresi linear berganda persamaan struktur 1, uji regresi linear berganda persamaan struktur 2, dan uji regresi linear berganda persamaan struktur 3. Perhitungan uji regresi berganda tersebut memperoleh hasil yang ditunjukan serta dijelaskan pada Tabel 7, berikut.

Berdasarkan hasil analisis regresi linier berganda persamaan 1 seperti yang disajikan pada Tabel 7, maka dapat dibuat persamaan struktural sebagai berikut:

$$
\mathrm{Y}_{1}=0,102 \mathrm{X}_{1}+0,101 \mathrm{X}_{2}+0,158 \mathrm{X}_{3}+0,535 \mathrm{X}_{4}+\varepsilon_{1}
$$

Nilai koefisien dari masing-masing variabel bernilai positif dengan nilai signifikansi uji t kurang dari 0,050. Hal ini menunjukkan bahwa seluruh variabel 
bebas memiliki pengaruh positif dan signifikan pada variabel penggunaan. Pada persamaan struktur 1 memilki nilai determinasi (Adjusted $R$ Square) sebesar 0,844 mempunyai arti bahwa sebesar $84,4 \%$ variabel bebas mempengaruhi variabel penggunaan, sedangkan sisanya sebesar $15,6 \%$ dijelaskan oleh faktor lain yang tidak dimasukkan ke dalam model. Hasil uji $\mathrm{F}$ (F test) yang terdapat pada Tabel 1, menunjukkan bahwa nilai $\mathrm{F}$ hitung pada persamaan struktur 1 sebesar 141,601 dengan nilai signifikansi $P$ value 0,000 yang lebih kecil dari $a=0,05$, ini berarti model yang digunakan pada penelitian ini adalah layak.

Tabel 7. Hasil Uji Regresi Linear Berganda Struktur 1

\begin{tabular}{|c|c|c|c|c|c|}
\hline \multirow[t]{2}{*}{ Model } & \multicolumn{2}{|c|}{$\begin{array}{l}\text { Unstandardized } \\
\text { Coefficients }\end{array}$} & \multirow{2}{*}{$\begin{array}{c}\begin{array}{c}\text { Standardized } \\
\text { Coefficients }\end{array} \\
\text { Beta }\end{array}$} & \multirow[t]{2}{*}{$\mathrm{t}$} & \multirow[t]{2}{*}{ Sig. } \\
\hline & $B$ & Std. Error & & & \\
\hline (Constant) & $-6,121$ & 1,587 & & $-3,857$ & 0,000 \\
\hline Kualitas Sistem & 0,102 & 0,047 & 0,179 & 2,145 & 0,034 \\
\hline Kualitas Informasi & 0,101 & 0,046 & 0,155 & 2,210 & 0,029 \\
\hline Kualitas Kolaborasi & 0,158 & 0,048 & 0,182 & 3,287 & 0,001 \\
\hline Kualitas Layanan & 0,535 & 0,056 & 0,749 & 9,619 & 0,000 \\
\hline Adjusted R Square & 0,844 & & & & \\
\hline $\mathrm{F}$ & 141,601 & & & & \\
\hline Sig. & $0,000^{a}$ & & & & \\
\hline
\end{tabular}

Sumber: Data Penelitian, 2020

Berdasarkan hasil analisis regresi linier berganda struktur 2 seperti yang disajikan pada Tabel 8, maka dapat dibuat persamaan struktural sebagai berikut.

Tabel 8. Hasil Uji Regresi Linear Berganda Struktur 2

\begin{tabular}{|c|c|c|c|c|c|}
\hline \multirow[t]{2}{*}{ Model } & \multicolumn{2}{|c|}{$\begin{array}{l}\text { Unstandardized } \\
\text { Coefficients }\end{array}$} & \multirow{2}{*}{$\begin{array}{c}\text { Standardized } \\
\text { Coefficients } \\
\text { Beta }\end{array}$} & \multirow[t]{2}{*}{$t$} & \multirow[t]{2}{*}{ Sig. } \\
\hline & B & Std. Error & & & \\
\hline (Constant) & $-3,770$ & 1,474 & & $-2,557$ & 0,012 \\
\hline Kualitas Sistem & 0,103 & 0,044 & 0,194 & 2,330 & 0,022 \\
\hline Kualitas Informasi & 0,104 & 0,042 & 0,173 & 2,468 & 0,015 \\
\hline Kualitas Kolaborasi & 0,121 & 0,045 & 0,149 & 2,692 & 0,008 \\
\hline Kualitas Layanan & 0,466 & 0,052 & 0,701 & 9,010 & 0,000 \\
\hline Adjusted R Square & 0,844 & & & & \\
\hline $\mathrm{F}$ & 141,940 & & & & \\
\hline Sig. & $0,000^{a}$ & & & & \\
\hline
\end{tabular}

Sumber: Data Penelitian, 2020

Nilai koefisien regresi setiap variabel bebas bernilai positif dengan nilai signifikansi uji t kurang dari 0,050. Hal ini menunjukkan bahwa setiap variabel memiliki pengaruh positif yang signifikan terhadap variabel kepuasan pengguna. Pada persamaan struktur 2 memiliki nilai determinasi (Adjusted $R$ Square) sebesar 0,844 mempunyai arti bahwa sebesar $84,4 \%$ variabel bebas mempengarui variabel kepuasan pengguna, sedangkan sisanya sebesar 15,6\% dijelaskan oleh faktor lain yang tidak dimasukkan ke dalam model. Hasil uji $\mathrm{F}$ hitung yang terdapat pada Tabel 2, menunjukkan bahwa nilai $\mathrm{F}$ hitung pada persamaan struktur 2 sebesar 141,940 dengan nilai signifikansi $P$ value 0,000 yang lebih kecil dari $\alpha=0,05$, ini berarti model yang digunakan pada penelitian ini adalah layak. 
Tabel 9. Hasil Uji Regresi Linear Berganda Struktur 3

\begin{tabular}{|c|c|c|c|c|c|}
\hline \multirow[t]{2}{*}{ Model } & \multicolumn{2}{|c|}{$\begin{array}{c}\text { Unstandardized } \\
\text { Coefficients }\end{array}$} & \multirow{2}{*}{$\begin{array}{c}\begin{array}{c}\text { Standardized } \\
\text { Coefficients }\end{array} \\
\text { Beta }\end{array}$} & \multirow[t]{2}{*}{$\mathrm{t}$} & \multirow[t]{2}{*}{ Sig. } \\
\hline & $\mathrm{B}$ & Std. Error & & & \\
\hline (Constant) & 9,124 & 1,302 & & 7,010 & 0,000 \\
\hline Penggunaan & 0,613 & 0,178 & 0,396 & 3,436 & 0,001 \\
\hline Kepuasan Pengguna & 0,651 & 0,192 & 0,391 & 3,393 & 0,001 \\
\hline Adjusted R Square & 0,556 & & & & \\
\hline $\mathrm{F}$ & 65,991 & & & & \\
\hline Sig. & $0,000^{a}$ & & & & \\
\hline
\end{tabular}

Sumber: Data Penelitian, 2020

Berdasarkan hasil analisis regresi linier berganda struktur 3 seperti yang disajikan pada Tabel 3, maka dapat dibuat persamaan tructural sebagai berikut: $\mathrm{Y}_{3}=0,613 \mathrm{Y}_{2}+0,651 \mathrm{Y}_{2}+\varepsilon_{3}$

Nilai koefisien regresi masing-masing variabel bernilai positif dengan nilai signifikansi uji t kurang dari 0,050. Pada persamaan struktur 3 memiliki nilai determinasi (Adjusted $R$ Square) sebesar 0,556 mempunyai arti bahwa sebesar $55,6 \%$ variabel bebas mempengaruhi variabel kinerja karyawan, mempengaruhi variabel kinerja karyawan, sedangkan sisanya sebesar $44,4 \%$ dijelaskan oleh faktor lain yang tidak dimasukkan ke dalam model. Hasil uji $F$ ( $F$ test) yang terdapat pada Tabel 3, menunjukkan bahwa nilai $\mathrm{F}$ hitung pada persamaan struktur 3 sebesar 65,991 dengan nilai signifikansi $P$ value 0,000 yang lebih kecil dari $\alpha=0,05$, ini berarti model yang digunakan pada penelitian ini adalah layak.

Hasil analisis dalam penelitian ini menunjukkan bahwa kualitas sistem berpengaruh positif dan signifikan pada penggunaan SIMAK BMN. Hal ini dapat dilihat pada Tabel 1, yang dimana nilai $\beta_{1}$ sebesar 0,102 dengan tingkat signifikansi uji t sebesar 0,034 yang lebih kecil dari $\alpha=0,05$. Hipotesis pertama $\left(\mathrm{H}_{1}\right)$ yaitu kualitas sistem berpengaruh positif pada penggunaan sistem diterima. Hasil penelitian ini mendukung hasil penelitian Purwanto \& Pawirosumarto (2017), (Ikhsani \& Yusuf, (2018) \& Krisdiantoro et al.,. (2018) yang memperoleh hasil bahwa Kualitas sistem berpengaruh positif pada penggunaan sistem.

Hasil analisis dalam penelitian ini menunjukkan bahwa kualitas informasi berpengaruh positif dan signifikan pada penggunaan SIMAK BMN. Hal ini dapat dilihat pada Tabel 1, yang dimana nilai $\beta_{2}$ sebesar 0,101 dengan tingkat signifikansi uji t sebesar 0,029 yang lebih kecil dari $\alpha=0,05$. Hipotesis kedua $\left(\mathrm{H}_{2}\right)$ yaitu kualitas informasi berpengaruh positif pada penggunaan sistem diterima. Hasil penelitian ini mendukung hasil penelitian Purwanto \& Pawirosumarto (2017), Subchan et al. (2012) \& Wiratama (2013) yang memperoleh hasil bahwa kualitas informasi berpengaruh signifikan pada penggunaan sistem.

Hasil analisis dalam penelitian ini menunjukkan bahwa kualitas kolaborasi berpengaruh positif dan signifikan pada penggunaan SIMAK BMN. Hal ini dapat dilihat pada Tabel 1 , yang dimana nilai $\beta_{3}$ sebesar 0,158 dengan tingkat signifikansi uji t sebesar 0,001 yang lebih kecil dari $\alpha=0,05$. Hipotesis ketiga $\left(\mathrm{H}_{3}\right)$ yaitu kualitas kolaborasi berpengaruh positif pada penggunaan sistem diterima. Hasil penelitian ini mendukung hasil penelitian $\mathrm{He} \&$ Yang (2016), Bhatti, et al. (2018), \& Subchan et al.,. (2012) yang memperoleh hasil bahwa 
kualitas kolaborasi berpengaruh signifikan dan memiliki dampak langsung dan tidak langsung terhadap pengguna sistem.

Hasil analisis dalam penelitian ini menunjukkan bahwa kualitas layanan berpengaruh positif dan signifikan pada penggunaan SIMAK BMN. Hal ini dapat dilihat pada Tabel 1, yang dimana nilai $\beta_{4}$ sebesar 0,535 dengan tingkat signifikansi uji t sebesar 0.000 yang lebih kecil dari $\alpha=0,05$. Hipotesis keempat $\left(\mathrm{H}_{4}\right)$ yaitu kualitas layanan berpengaruh positif pada penggunaan sistem diterima. Hasil penelitian ini mendukung hasil penelitian Purwanto \& Pawirosumarto (2017), Groho et al. (2014), \& Ikhsani \& Yusuf (2018), yang memperoleh hasil bahwa kualitas layanan berpengaruh terhadap penggunaan hal tersebut dikarenakan layanan yang diberikan oleh sistem pada saat digunakan oleh pengguna pada saat menyelesaikan pekerjaan sudah optimal.

Hasil analisis dalam penelitian ini menunjukkan bahwa kualitas sistem berpengaruh positif dan signifikan pada kepuasan pengguna SIMAK BMN. Hal ini dapat dilihat pada Tabel 2, yang dimana nilai $\beta_{1}$ sebesar 0,103 dengan tingkat signifikansi uji t sebesar 0,022 yang lebih kecil dari $\alpha=0,05$. Hipotesis kelima $\left(\mathrm{H}_{5}\right)$ yaitu kualitas sistem berpengaruh positif pada kepuasan pengguna diterima. Hasil penelitian ini mendukung hasil penelitian Rukmiyati \& Budiartha (2015), Rahardiyanti (2012), \& Swandewi et al.,. (2017) yang memperoleh hasil bahwa Kualitas sistem berpengaruh positif pada kepuasan pengguna.

Hasil analisis dalam penelitian ini menunjukkan bahwa kualitas informasi berpengaruh positif dan signifikan pada kepuasan pengguna SIMAK BMN. Hal ini dapat dilihat pada Tabel 2, yang dimana nilai $\beta_{2}$ sebesar 0,104 dengan tingkat signifikansi uji $t$ sebesar 0.015 yang lebih kecil dari $\alpha=0,05$. Hipotesis keenam $\left(\mathrm{H}_{6}\right)$ yaitu kualitas informasi berpengaruh positif pada kepuasan pengguna diterima. Hasil penelitian ini mendukung hasil penelitian Shinta (2018), Prasojo \& Pratomo (2015) \& Purwanto \& Pawirosumarto (2017) yang memperoleh hasil bahwa kualitas informasi berpengaruh signifikan pada kepuasan pengguna.

Hasil analisis dalam penelitian ini menunjukkan bahwa kualitas kolaborasi berpengaruh positif dan signifikan pada kepuasan pengguna SIMAK BMN. Hal ini dapat dilihat pada Tabel 2, yang dimana nilai $\beta_{3}$ sebesar 0,121 dengan tingkat signifikansi uji $\mathrm{t}$ sebesar 0.008 yang lebih kecil dari $\alpha=0,05$. Hipotesis ketujuh $\left(\mathrm{H}_{7}\right)$ yaitu kualitas kolaborasi berpengaruh positif pada kepuasan pengguna diterima. Hasil penelitian ini mendukung hasil penelitian He \& Yang (2016), Bhatti et al. (2018), \& Subchan et al.,. (2012) yang memperoleh hasil bahwa kualitas kolaborasi berpengaruh signifikan dan memiliki dampak langsung dan tidak langsung pada kepuasan pengguna sistem.

Hasil analisis dalam penelitian ini menunjukkan bahwa kualitas layanan berpengaruh positif dan signifikan pada kepuasan pengguna SIMAK BMN. Hal ini dapat dilihat pada Tabel 2, yang dimana nilai $\beta_{4}$ sebesar 0,466 dengan tingkat signifikansi uji t sebesar 0.000 yang lebih kecil dari $\alpha=0,05$. Hipotesis kedelapan $\left(\mathrm{H}_{8}\right)$ yaitu kualitas layanan berpengaruh positif pada kepuasan pengguna diterima. Hasil penelitian ini mendukung hasil penelitian Septianita et al.,. (2014), Prasojo \& Pratomo (2015), \& Shinta (2018), yang memperoleh hasil bahwa kualitas layanan berpengaruh positif terhadap kepuasan pengguna hal tersebut 
dikarenakan layanan yang diberikan oleh sistem pada saat digunakan oleh pengguna pada saat menyelesaikan pekerjaan sudah optimal sehingga memberikan kepuasan tersendiri bagi pengguna.

Hasil analisis dalam penelitian ini menunjukkan bahwa penggunaan sistem berpengaruh positif dan signifikan pada kinerja karyawan satuan kerja KPKNL wilayah Denpasar. Hal ini dapat dilihat pada Tabel 3, yang dimana nilai $\beta_{5}$ sebesar 0,613 dengan tingkat signifikansi uji t sebesar 0,001 yang lebih kecil dari $\alpha=0,05$. Hipotesis kesembilan $\left(\mathrm{H}_{9}\right)$ yaitu penggunaan sistem berpengaruh positif pada kinerja karyawan diterima. Hasil penelitian ini mendukung hasil penelitian Muzakki et al., (2016), Marlinawati \& Suryana (2013), \& Antasari (2015), yang memperoleh hasil bahwa penggunaan sistem berpengaruh positif pada kinerja karyawan.

Hasil analisis dalam penelitian ini menunjukkan bahwa kepuasan pengguna berpengaruh positif dan signifikan pada kinerja karyawan satuan kerja KPKNL Denpasar. Hal ini dapat dilihat pada Tabel 3, yang dimana nilai $\beta_{6}$ sebesar 0,651 dengan tingkat signifikansi uji t sebesar 0,001 yang lebih kecil dari $\alpha=0,05$. Hipotesis kesepuluh $\left(\mathrm{H}_{10}\right)$ yaitu kepuasan pengguna berpengaruh positif pada kinerja karyawan diterima. Hasil penelitian ini mendukung hasil penelitian Wijaya, (2018), Dewi et al., (2017), \& Iranto (2012), yang memperoleh hasil bahwa kepuasan pengguna berpengaruh positif pada kinerja karyawan.

\section{SIMPULAN}

Penelitian ini menghasilkan simpulan mengenai pengaruh penggunaan SIMAK BMN dan kepuasan pengguna pada kinerja karyawan satuan kerja KPKNL wilayah Denpasar. Hasil dari penelitian ini yang dimana kualitas sistem, kualitas informasi, kualitas kolaborasi dan kualitas layanan berpengaruh positif dan signifikan pada penggunaan sistem. kualitas sistem, kualitas informasi, kualitas kolaborasi dan kualitas layanan berpengaruh positif dan signifikan pada kepuasan pengguna, serta penggunaan sistem dan kepuasan penguna berpengaruh positif dan signifikan pada kinerja karyawan satuan kerja KPKNL wilayah Denpasar.

Pada penelitian ini membuktikan semua variabel yang secara teori memengaruhi penggunaan dan kepuasan pengguna pada kinerja karyawan juga berpengaruh secara nyata melalui penelitian ini, hal ini adanya Theory Acceptance Model (TAM), Model Kesuksesan DeLone and McLean, dan Collaboration Theory yang menjelaskan alasan penggunaan sistem informasi menggunakan SIMAK BMN untuk membantu pekerjaannya, bagaimana pengguna merasa puas saat menggunakan SIMAK BMN saat melakukan pekerjaannya, dan bagaimana SIMAK BMN membantu pengguna dalam meningkatkan kinerjanya.

\section{REFERENSI}

Antasari, K. C. (2015). Pengaruh Efektivitas Sistem Informasi Akuntansi dan Penggunaan Teknologi Informasi Pada Kinerja Individual Dengan Kepuasan Kerja Sebagai Variabel Pemoderasi. E- Jurnal Akuntansi Universitas Udayana, 10(2), 354-369.

Bhatti, Z. A., Baile, S., \& Yasin, H. M. (2018). Assessing enterprise wiki success from the perspective of end-users: an empirical approach. Behaviour and 
Information Technology, 37(12), 1177-1193. https://doi.org/10.1080/0144929X.2018.1488992

DeLone, W. H., \& McLean, E. R. (1992). Information Systems Success The Quest for the dependent variabel. Infomation System Research, 3(1), 60-95.

DeLone, W. H., \& McLean, E. R. (2003). The DeLone and McLean model of information systems success: A ten-year update. Journal of Management Information Systems. https:/ / doi.org/10.1080/07421222.2003.11045748

DeLone, W., \& McLean, E. (1992). The Quest for the Dependent Variable. Information Systems Research, 3(1), 60-65. https://doi.org/10.1287/isre.3.1.60

Dewi, P. A. R., Badera, I. D. N., \& Wirama, D. G. (2017). Dukungan Manajemen Puncak, Kualitas Sistem, Kualitas Informasi Sebagai Prediktor Kepuasan Pengguna dan Implikasinya Pada Kinerja Pegawai. 6, 2529-2552.

Groho, T. C. W., Winarno, W. W., \& Permanasari, A. E. (2014). Evaluasi Kesuksesan Implementasi Aplikasi Pengelolaan Tugas Belajar di BPK. Seminar Nasional Informatika (SemnasIF) 2014.

He, W., \& Yang, L. (2016). Using wikis in team collaboration: A media capability perspective. Information and Management, 53(7), 846-856. https://doi.org/10.1016/j.im.2016.06.009

Ikhsani, D. W., \& Yusuf, M. (2018). Pengaruh Kualitas Sistem, Kualitas Informasi, Dan Kualitas Pelayanan Terhadap Penggunaan Sistem Dan Kepuasan Pengguna Sistem Serta Pengaruh Penggunaan Sistem Dan Kepuasan Pengguna Sistem Terhadap Net Benefit Sipkd (Studi Pada Opd Kabupaten Wonogiri). Magisma: Jurnal Ilmiah Ekonomi Dan Bisnis, 6(2), 20-30. https://doi.org/10.35829/magisma.v6i2.31

Iranto, B. D. (2012). Pengaruh Kepuasan Pengguna Sistem Informasi Terhadap Kinerja Individu (Studi pada PT . PLN (PERSERO) Distribusi Jawa Tengah dan DIY).

Jogiyanto. (2007). Sistem Informasi Keperilakuan (Revisi). Yogyakarta: ANDI.

Krisdiantoro, Y., Subekti, I., \& Prihatiningtias, Y. W. (2018). Pengaruh Kualitas Sistem Dan Kualitas Informasi Terhadap Manfaat Bersih Dengan Intensitas Penggunaan Sebagai Variabel Mediasi. Jurnal Akuntansi Aktual, 5(2), 149167.

Krisna Dewi, N., \& Mertha, M. (2016). Pengaruh Perceived Usefulness, Perceived Ease of Use Dan Penggunaan Software Audit Pada Kinerja Auditor Internal. E-Jurnal Akuntansi, 17(2), 1485-1515.

Marlinawati, N. M. A., \& Suryana, I. G. . A. (2013). Pengaruh Penggunaan Teknologi Informasi, Efektivitas Sistem Informasi Akuntansi, Kepercayaan Atas Sistem Informasi Akuntansi, Dan Kesesuaian Tugas Pada Kinerja Karyawan Lembaga Perkreditan Desa Di Kabupaten Badung. E-Jurnal Akuntansi, 2(2), 388-401.

Muzakki, M. H., Susilo, H., \& Yuniarto, S. R. (2016). Pengaruh Penggunaan Teknologi Informasi Terhadap Kinerja Karyawan (Studi Pada Karyawan PT. TELKOM Pusat Divisi Regional V Surabaya). Jurnal Administrasi Bisnis, 39(2), 169-175.

Permadi, A. (2017). Pendekatan Model DeLone dan McLean Dalam Kesuksesan Implementasi Sistem Informasi Manajemen Daerah (SIMDA) Keuangan. 62.

Prasojo, L. H., \& Pratomo, D. (2015). Pengaruh Kualitas Informasi, Kualitas Sistem, dan Kualitas Layanan Aplikasi Rail Ticket System (RTS) Terhadap 
Kepuasan Pengguna Sistem (Studi Kasus pada PT. Kereta Api Indonesia (Persero) DAOP 2 Bandung). E-Proceeding of Management, 2(1), 555-562.

Rahardiyanti. (2012). Evaluasi Efektivitas Sistem Informasi Manajemen dan Akuntansi Barang Milik Negara (SIMAK-BMN) di Departemen Kebudayaan dan Pariwisata Republik Indonesia. Journal of Applied Finance and Accounting.

Rukmiyati, N. M. S., \& Budiartha, I. K. (2015). Pengaruh Kualitas Sistem Informasi, Kualitas Informasi Dan Perceived Usefulness Pada Kepuasan Pengguna Akhir Software Akuntansi (Studi Empiris Pada Hotel Berbintang Di Provinsi Bali). Journal of Management Information Systems, 2(1), 1-11. https://doi.org/10.1016/j.giq.2003.08.002

S.K, Purwanto \& Pawirosumarto, S. (2017). Pengaruh Kualitas Sistem, Kualitas Informasi, dan Kualitas Layanan Terhadap Penggunaan Sistem E-Learning Di Program Pascasarjana Universitas Mercu Buana. XXI(02), 282-305.

Sabario, R., \& Jaya, H. (2017). Pengaruh Aplikasi Sistem Informasi Manajemen Akuntansi Barang Milik Negara (SIMAK-BMN) dan Kinerja Pegawai Terhadap Efektivitas Pelaporan Aset (Studi Kasus Pada Pengadilan Negeri Batam). Measurement, 11(1), 11-25.

Seddon, P. B., \& Kiew, M.-Y. (1996). A Partial Test And Development of Delone and Mclean's Model of is Succes. Australasian Journal of Information Systems, 4(1), 90-109. Retrieved from http://journal.acs.org.au/index.php/ajis/article/view/379/345

Septianita, W., Winarno, W. A., \& Arif, A. (2014). Pengaruh Kualitas Sistem, Kualitas Informasi, Kualitas Pelayanan Rail Ticketing System (RTS) Terhadap Kepuasan Pengguna (Studi Empris Pada PT. KERETA API INDONESIA $\begin{array}{lllll}\text { (PERSERO) DAOP } 9 & 9 \\ \text { JEMBER). } & 1(1),\end{array}$ https://doi.org/10.19184/ ejeba.v1i1.570

Shinta, M. R. (2018). Pengaruh Kualitas Layanan, Kualitas Sistem dan Kualitas Informasi Pada Sistem Informasi Akuntansi Terhadap Kinerja Karyawan (Studi pada Karyawan Pengguna Software Acosys UMKM di Bandar Lampung). https://doi.org/10.1017/CBO9781107415324.004

Subchan, N., Astuti, E. S., \& Kertahadi. (2012). Mengukur Efektivitas Sistem Informasi dan Mengetahui Kesuksesan Portal Akademik (SIAM) On-Line (Studi Kasus Terhadap Pengguna di Program Pendidikan Vokasi Universitas Brawijaya). Jurnal Profit, 117-134.

Swandewi, L. P., Ariyanto, D., \& Dewi, L. G. K. (2017). Kepuasan Pengguna Sistem Informasi Akuntansi pada Lembaga Perkreditan Desa di Kabupaten Buleleng. E-Jurnal Akuntansi Universitas Udayana, 19(3), 1803-1831.

Wijaya, S. (2018). Pengaruh Tingkat Kepuasan Pengguna Aplikasi Terhadap Kinerja Individu Pengguna Aplikasi Sistem Absensi Online di STMIK Bali. 4(April), 2125.

Wijaya, T. N., \& Hamidah, H. (2018). Institusionalisasi Paradigma Revenue Center Untuk Pengelolaan Aset Negara Yang Optimal (Studi Kasus Pada Kantor Pelayanan Kekayaan Negara dan Lelang Surabaya). Media Riset $\begin{array}{lllll}\text { Akuntansi, Auditing } \mathcal{E} \quad \text { Informasi, } & 17(2), & 173 .\end{array}$ https://doi.org/https://doi.org/10.25105/mraai.v17i2.2541

Wiratama, D. (2013). Pengaruh Kualitas Informasi, Persepsi Kebermanfaatan dan Computer Self Efficacy Terhadap Penggunaan Internet Oleh Mahasiswa Sebagai 
Salah Satu Sumber Pustaka. (434).

Wirawan, B. S. (2016). Pengaruh Efektivitas Penggunaan Sistem Informasi Akuntansi Berbasis Teknologi Informasi, Kepercayaan, Kemampuan Teknik Personal, dan Dukungan Manajemen Terhadap Kinerja Individual Pada Bank Perkreditan Rakyat di Kabupaten Badung. Skripsi.

Yuhelson, Ariyanto, D., Ernawati, Soejono, F., \& Dewi, S. P. (2020). Digital economy and financial inclusion. Journal of Environmental Treatment Techniques, 8(1), 241-243. 